\title{
TEACHING STYLE DOSEN MATAKULIAH EVALUASI PEMBELAJARAN SD
}

\author{
Dwi Agus Setiawan \\ Universitas Kanjuruhan Malang \\ Setiawankanjuruhan1988@gmail.com
}

\begin{abstract}
Abstrak
Penelitian ini bertujuan untuk mendeskripsikan teaching style dosen pengajar matakuliah Evaluasi Pembelajaran SD di Universitas Kanjuruhan Malang. Penelitian ini Merupakan penelitian Deskriptif dengan pendekatan kualitatif Study kasus dilapangan. Setting dalam penelitian ini Pada Mahasiswa semester VI 2017/2018. Pengumpulan data dilakukan dengan mengadakan observasi dan wawancara. Data dianalisis kemudian ditarik kesimpulan. Pemeriksaan keabsahan data dengan ketekunan pengamatan, pemeriksaan teman sejawat dan triangulasi data. Hasil penelitian ini menunjukkan bahwa : (1) Dosen lebih sering menggunakan gaya mengajar klasik, (2) Dosen jarang menggunakan media dikarenakan membuat dan menggunakan media itu ribet, (3) Dosen menggunakan metode ceramah, tanya jawab, dan penugasan,dan diskusi kelas (4) Dosen mengombinasikan gaya mengajar satu dengan yang lainnya. (5)karakteristik setiap masing masing dosen pengampu matakuliah memilki kompetensi mengajar yang berbeda, ada yang gaya mengajarnya klasik, interaksional dan teknologis dan personalisasi.Penelitian ini menunjukkan bahwa dosen menggunakan gaya mengajar klasik, namun diselingi dengan gaya mengajar lainnya yaitu teknologis, personalisasi dan interaksional. dosen berupaya membuat variasi gaya mengajar dalam pembelajaran, namun belum terlihat jelas.
\end{abstract}

Kata Kunci: Teaching Style, dosen

\begin{abstract}
Teaching essentially aims to deliver students to achieve the learning objectives that have been planned previously. In practice, the teaching behavior shown by the lecturers is very diverse, although the meaning is the same. A variety of lecturers' behavior is called teaching style. Each lecturer has different teaching styles. The role of lecturers in class is very large in the development and improvement of student learning outcomes. This study aims to describe the teaching style of teaching lecturers of the Evaluation of Elementary Learning at the University of Kanjuruhan Malang. This research descriptive qualitative approach case study field. Setting research at the University of Kanjuruhan Malang, In the 6th semester of 2017/2018. Data collection is done by conducting observation and interview. Data analysis is done by giving meaning to the data collected, then drawn conclusion. Inspection of data validity with observational persistence, peer examination and data triangulation. The results of this study indicate that: (1) Lecturers more often use classical teaching style, (2) Lecturers rarely use the media due to make and use the media is complicated, (3) Lecturer using lecture, question and answer method, 4) Lecturers combine teaching styles with each other. (5) the characteristics of each lecturers have different teaching competencies, some of which are classical, interactional and technological and personalized teaching styles. The conclusions in this study indicate that the lecturer uses the classical teaching style, but interspersed with other teaching styles of technological, personalization and interactional. lecturers try to make variations of teaching styles in learning, but not yet clearly visible.
\end{abstract}

Keywords: Teaching Style, lecturer 


\section{PENDAHULUAN}

Pendidikan pada dasarnya merupakan sebuah investasi jangka panjang, dengan hasil dari proses pendidikan akan dirasakan baik untuk saat ini maupun untuk waktu yang akan datang. Dengan kondisi yang akan datang dapat dibentuk melalui pendidikan yang sedang kita lakukan sekarang, dalam artian bahwa pendidikan harus dapat menyiapkan dan menjawab tantangan dan kebutuhan di masa yang akan dating dalam Undang-Undang RI No. 20 Tahun 2003 (pasal 1 ayat 1),menegaskan bahwa pendidikan merupakan usaha sadar dan terencana dalam mewujudkan suasana belajar dan pembelajaran agar peserta didik secara aktif mengembangkan potensi dirinya untuk dapat memiliki kekuatan spiritual, pengendalian diri keagamaan, , akhlak mulia, kepribadian, kecerdasan, , serta keterampilan yang diperlukan dirinya, dalam masayarakat, bangsa dan negara". Untuk mewujudkan hal tersebut di atas, sekolah harus dibangun sedemikian rupa sehingga Dosen tidak hanya mentransfer isi kurikulum, tetapi lebih dari itu, menciptakan bagaimana proses pembelajaran dapat memberikan segala sesuatu yang dibutuhkan mahasiswa. Untuk mewujudkan hal tersebut di atas, universitas harus dibangun sedemikian rupa sehingga Dosen tidak hanya mentransfer isi kurikulum dan materi saja, tetapi lebih dari itu, menciptakan bagaimana proses pembelajaran dapat memberikan segala sesuatu yang dibutuhkan Mahasiswa.

Pembelajaran pada hakikatnya sangat terkait dengan bagaimana membangun interaksi yang baik antara dua komponen penting, yaitu guru dan siswa. Interaksi yang baik dapat digambarkan dengan suatu kondisi di mana dosen dapat membuat Mahasiswa belajar dengan mudah dan terdorong oleh kemauannya sendiri untuk mempelajari apa yang ada dalam kurikulum sebagai kebutuhan mereka. Ali, dkk (2010)menyatakan bahwa mengajar merupakan bagaian dari proses pencapaian tujuan untuk mencerdaskan peserta didik dalam mencapai tujuan yang telah direncanakan sebelumnya. Dalam prakteknya, perilaku mengajar yang dipertunjukkan dosen sangat beraneka ragam, meskipun maksudnya sama. Beragam perilaku Dosen mengajar ini jika ditelusuri akan diperoleh gambaran tentang pola umum interaksi antara dosen, isi atau bahan pelajaran, dan siswa. "Gaya Mengajar" atau "Teaching Style". Thoifuri (2013) menambahkan gaya mengajar dosen adalah bentuk penampilan dosen ketika mengajar, baik bersifat kurikuler ataupun psikologis. Gaya mengajar bersifat kurikuler merupakan dosen mengajar disesuaikan dengan tujuan dan sifat matakuliah tertentu. Sedangkan gaya mengajar yang bersifat psikologis adalah dosen mengajar yang disesuaikan dengan motivasi Mahasiswa, pengelolaan kelas dan evaluasi belajar. Gaya seseorang satu dengan yang lain dalam satu aspek mungkin bisasama, seperti halnya gaya berpakaiannya sama, gaya bicaranya sama, dan gaya pergaulannya sama, akan tetapi tidak mungkin bisa sama semua dalam gaya seseorang. Demikian juga dengan Dosen, Dosen sebagai manusia mempunyai gaya yang berbeda satu dengan yang lainnya pada saat mengajar di kelas, walaupun mempunyai tujuan yang sama, yaitu menyampaikan pengetahuan, 
membentuk sikap Mahasiswa dan menjadikan Mahasiswa terampil dan berkarya. Gaya mengajar Dosen pada prinsipnya sulit dirubah karena sudah menjadi pembawaan sejak kecil. Dengan kata lain merupakan bahwa, style dosen menjadi faktor penting dalam menentukan keberhasilan Mahasiswa dalam menempuh sajian Matakuliah Evaluasi Pembelajaran dengan bobot 3 SKS. Senada dengan Arikunto (2008:20) menegaskan bahwa denagn adanya sebuah Evaluasi Pembelajaran merupakan hal yang sangat penting dalam runtutan proses pembelajaran, dan dengan evaluasi itu dapat diukur seberapa berhasilnya sebuah proses pembelajaran yang sedang berlangsung. Ada banyak hal dan indicator untuk dapat menilai peserta didik bahwa evaluasi dikatakan berhasil, tentu saja ini akan bergantung pada sebuah jenis instrument yang digunakan dalam sebuah evaluasi.

Selama ini Mata Kuliah Evaluasi Pendidikan memang bisa dikatakan menjadi matakuliah pilihan yang di rasa cukup sulit dan cukup berat dan menakutkan bagi mahasiswa karena sifat mata kuliah yang semi eksak dengan bobot 4 sks dengan jenis evaluasi yang akan terlihat jelas pada karya mahasiswa itu berupa prodak evaluasi dan secara obyektif dan subjekctif dapat ditunjukkan letak kesalahan dan kekurangan pada gambar/karya dan hasil yang dibuat oleh mahasiswa itu dengan sangat terbuka. Akan tetapi selama ini dalam assessment penilaian yang digunakan pada Mata Kuliah Evaluasi Pendidiakan hanya berupa hasil akhir berupa gambar yang dibuat oleh mahasiswa dalam membuat suatu Instrumen Penelitian dan kisi kisi intrumen penelitian saja tanpa mengembangkan butir soal evalusi dalam mengemas soal dan penilaiannya. Oleh sebab itu peneliti mencoba untuk melihat Teaching Style pada saat mengajar dengan system evaluasi yang juga menjadikan "proses " bahwa sebagai bagian dari penilaian dan assesment untuk mendapatkan hasil yang lebih optimal baik motivasi belajarnya bagi mahasiswa sekaligus juga objektifitas dari dosen sendiri. Setiap Dosen yang mengajar di kelas terutama dikampus Universitas Kanjuruhan Malang tersebut pastilah memiliki gaya mengajar yang berbeda satu dengan yang lain. Penerapan gaya mengajar guru ini disesuaikan dengan kondisi kelas dan materi yang disampaikan. Masing-masing guru mempunyai gaya mengajar yang khas yang tidak dimiliki oleh Dosen yang lain dan tidak dapat ditiru. Berdasarkan observasi dan wawancara dengan salah satu Dosen pengampu matakuliah Evaluasi Pembelajaran SD pada mahasisiwa semester VI di Universitas Kanjruhan Malang program Studi Pendidikan Dasar, dapat diketahui dengan pasti bahwa masingmasing Dosen memiliki gaya mengajar yang berbeda setiap mengajar. Hal itu dikarenakan perbedaan karakter Mahasiswa, kondisi kelas, dan materi yang akan disampaikan.

Dosen juga memakai gaya mengajar klasik karena materi yang disampaikan mudah dipahami Mahasiswa, namun terkadang Dosen lain juga menggabungkan dari beberapa gaya mengajar tersebut untuk membuat mahasiswa lebih paham dengan materi yang di sampaikan, misalnya menggunakan media 
dengan pembaharuan ilmu dan pengetahuan yang sekarang ini. Tidak jarang pula Dosen menentukan beberapa aturan khusus pada kelasnya agar siswa tidak bertindak di luar batas. Mengingat sikap Mahasiswa yang sangat aktif dosen harus pandai dalam menguasai kelas dan materi. Berdasarkan kenyataan tersebut, peneliti tertarik untuk mengetahui lebih dalam tentang gaya mengajar masing masing Dosen Pengampu Matakuliah Evaluasi Pembelajaran dikelas pada mahasiswa semester 6. Peneliti mengambil mengambil Mahasisiwa Semester 6 karena pembelajaran pada matakuliah ini ada pada semester 6 sehingga membuat peneliti lebih mudah untuk menentukan waktu penelitian dan mengatur pertemuan sesuai jam pada matakuliah. Peneliti ingin menambah wawasan dan pengalaman tentang gaya mengajar apa saja yang seharusnya diterapkan di Kelas pada jenjang perguruan tinggi yang sangat mendukung dengan keinginan peneliti. Bertitik tolak dari penelitian sebelumnya maka peneliti mencoba melakukan analisis pembelajaran dalam gaya pengajaran dosen, serupa dengan subjek penelitian 3 dosen pada matakuliah evaluasi pembelajaran yang berbeda dengan mahasiswa. Peneliti hendak melakukan penelitian tentang teaching style dosen pengajar matakuliah evaluasi pembelajaran yang berpengaruh terhadap tingkat pemhaman mahahsiswa semester VI. Oleh sebab itu, peneliti akan mengadakan penelitian dengan tujuan untuk mengeksplorasi atau menemukan tingkat gaya mengajara dosen dengan style pengajaran yang menarik minar dan perhatian mahasisiwa sehingga mahasiswa dapat memperoleh nilai yang di harapkan sesuai dengan bobot SKS yang sudah di tentukan oleh lembaga dan jurusan.

\section{METODE PENELITIAN}

Penelitian ini bertujuan untuk mendeskripsikan gaya mengajar Dosen dikelas C,D,E,F yang sesuai dengan kondisi di lapangan, Subjek dalam penelitian ini adalah 4 Dosen pengampu matakuliah Evaluasi Pembelajaran SD, sehingga penelitian ini jenis kualitatif study kasus dengan Metode yang digunakan dalam penelitian ini adalah Penelitian deskriptif bertujuan untuk menganalisi pengajaran secara sistematis, faktual, dan akurat mengenai fakta-fakta dan sifat-sifat populasi atau daerah terntentu (Embong, Noor, Hashim, Ali, \& Shaari, 2012) . Teknik pengumpulan data menggunakan metode observasi, wawancara, dan dokumentasi. Instrumen dalam penelitian ini adalah lembar observasi, pedoman wawancara, dan dokumen.Data yang dikumpulkan pada penelitian deskriptif berupa kata-kata, gambar, dan bukan angka-angka, dengan demikian laporan peneliti akan berisi kutipan-kutipan data untuk memberi gambaran penyajian laporan (Moleong, 2006). Penelitian ini berdasarkan pengumpulan datanya merupakan penelitian lapangan. Penelitian lapangan berarti penelitian yang mengambil data dari lapangan. Lapangan yang dimaksud dalam penelitian ini adalah Universitas Kanjuruhan Malang,Sedangkan berdasarkan analisis datanya merupakan penelitian kualitatif, sehingga yang digunakan adalah pendekatan kualitatif 
(Satori, D dan Komariah, 2011). Instrumen yang digunakan dalam penelitian ini adalah pedoman. 1.Observasi.2. Wawancara 3. Catatatn Lapangan

Proses analisis data pada penelitian kualitatif pada prinsipnya dilakukan secara berkesinambungan yaitu sejak sebelum memasuki lapangan, memasuki lapangan, selama di lapangan, dan setelah selesai di lapangan. Hal ini sebagaimana telah dinyatakan oleh Nasution dalam (Satori, n.d.)data di proses dan kemudia analisis sehingga telah dimulai sejak merumuskan dan menjelaskan masalah, sebelum terjun meneliti hingga penulisan hasil penelitian. Akan tetapi yang lebih alot dan lebih terfokus dalam menganalisis data adalah selama proses di lapangan bersamaan dengan pengumpulan data. Analisis data dalam penelitian ini menggunakan model alir (flow model) Miles dan Huberman (dalam Sugiyono, 2011$)$ yang meliputi aktivitas sebagai berikut. (1).Reduksi data (2.)display data ((3).kesimpulan data dan Data yang terkumpul perlu diperiksa keabsahannya agar dapat digunakan untuk menarik kesimpulan secara valid. Pengecekan keabsahan data dilakukan dengan teknik kriteria derajat kepercayaan (Moleong, 2006:237). Penentuan derajat kepercayaan dalam penelitian ini dilakukan dengan 3 cara seperti yang akan dijelaskan sebagai berikut.1. Ketekunan Pengamatan(2.) Pemeriksaan Teman Sejawat (3) . Triangulasi

\section{HASIL DAN PEMBAHASAN}

Berdasarkan hasil data tersebut dapat terlihat jelas bahwa dosen menggunakan bahan ajar RPS berupa sejumlah sajian informasi dan ide yang sudah populer dan diketahui oleh mahasiswa dalam rancangan perkuliahan awal ataau disebut RPS. Bahan matakuliah tersebut bersifat obyektif, jelas dan logis. Sehingga bahan perkuliahan tersebut dikategorikan dalam gaya mengajar klasik. Proses penyampaian materi oleh dosen dikelas Pgsd angkatan 2014 kelas F yaitu berdasarkan urutan tertentu, dimana mata perkuliahan tersebut memang sudah diatur sedemikian rupa oleh para ahlinya masing-masing. Dalam hal ini proses penyampaian pelajaran tersebut dikategorikan dalam gaya mengajar klasik. Berdasarkan hasil data tersebut dapat terlihat jelas bahwa dosen menggunakan bahan pelajaran berupa sejumlah informasi dan ide yang sudah populer dan diketahui oleh mahasiswa. Bahan tersebut bersifat jelas dan logis. Sehingga bahan pelajaran tersebut dikategorikan dalam gaya mengajar klasik. Pada proses penyampaian pelajaran, dosen masih menerapkan cara mendidik dengan budaya yang dianggap benar dengan menyampaikan nilai-lama dari generasi terdahulu. Apalagi dosen hanya menggunakan urutan tertentu dalam penyampaiannya, sehingga proses penyampaian pelajaran yang seperti ini dikategorikan dalam gaya mengajar klasik. Di sisi lain dosen juga memberikan stimulan berupa pertanyaan pada siswa untuk dijawab. Proses penyampaian yang seperti itu dikategorikan dalam gaya mengajar teknologis.

Selain itu, dalam proses penyampaian pelajaran muncul percakapan dua arah. Dengan demikian terjadilah tanya jawab dan interaksi belajar yang menyenangkan atau timbal balik antara dosen dengan mahasiswa. Kondisi seperti ini dikategorikan sebagai gaya mengajar interaksional. Belajar yang bermanfaat pada dirinya memang sesuatu yang harus dilakukan oleh mahasiswa. Hal itu muncul saat peneliti mengamati proses pembelajaran di kelas. Saat pembelajaran, dosen juga menunjukkan media sehingga mempermudah mahasiswa dalam 
memahami pelajaran. mahaiswa dengan cepat merespon stimulant guru dengan bantuan media pembelajaran. Peran mahasiswa yang demikian termasuk dalam gaya mengajar teknologis. Dalam proses pembelajaran dosen menggunakan media pembelajaran, sehingga ketika terjadi percakapan dua arah antara mahasiswa dan dosen, mahasiswa dapat mengemukakan pendapatnya yang berhubungan tentang realita di kehidupannya dengan baik. Selain itu, mahasiswa juga mendengarkan pendapat temannya, sehingga ketika ada mahasiswa yang sedang menjawab pertanyaan dosen, mahasiswa lain menyimak. Keadaan yang demikian dikategorikan dalam gaya mengajar dosen interaksional.

Peran dosen selama proses pembelajaran yaitu lebih dominan dari pada mahasiswa. Hal ini disebabkan kebiasaan dosen yang hanya menyampaikan bahan ajar selama proses pembelajaran. dosen juga bertindak seperti penguasa di kelas tersebut. Perintah yang diberikan dosen harus langsung dilaksanakan oleh mahasiswa. Hal ini dilakukan untuk melatih kedisiplinan mahasiswa agar tidak terlalu meremehkan perintah dosennya. Meskipun begitu, dosen benar-benar sudah ahli dalam pelajaran tersebut, sehingga tanpa melihat buku pun dosen dapat menyampaikan pelajaran dengan sangat baik. Kondisi demikian itu dikategorikan dalam gaya mengajar dosen klasik. Selama proses pembelajaran dosen berperan sebagai pembimbing bagi mahasiswa untuk belajar. Kondisi ini disebut gaya mengajar personalisasi. Komepetensi mengajar masing masing dosen memeiliki gaya mengajar yang berbeda, seperti yang terdapat pada pola pengajaran di kelas ini seorang dosen sudah membiasakan kepada mahasisiwanya untuk melakukan diskusi dengan adanya penemuan terbaru dengan kemmpuan berfikir kritis.

Pada tahapan selanjutnya Berdasarkan hasil data tersebut dapat kita lihat dengan jelas antara kelas F dan D, kedua Dosen menggunakan bahan pelajaran berupa sejumlah informasi dan ide yang sudah populer dan diketahui oleh Mahasiswa. Namun ada sedikit perbedaan pada bahan pelajaran, dosen kelas $\mathrm{F}$ menggunakan bahan yang bersifat obyektif, jelas dan logis sedangkan dosen kelas $\mathrm{C}$ hanya menggunakan bahan pelajaran yang bersifat jelas dan logis. Meskipun begitu, dari kedua bahan pelajaran tersebut sama-sama dikategorikan dalam gaya mengajar klasik. Proses penyampaian materi oleh dosen kelas F yaitu berdasarkan urutan tertentu, dimana mata pelajaran tersebut memang sudah diatur sedemikian rupa oleh para ahlinya masing-masing. Sedangkan Dosen kelas D masih menerapkan cara mendidik dengan budaya yang dianggap benar dengan menyampaikan nilai-lama dari generasi terdahulu. Apalagi dosen hanya menggunakan urutan tertentu dalam penyampaiannya. Proses penyampaian materi perkuliahan oleh dosen kelas $\mathrm{F}$ dan $\mathrm{D}, \mathrm{C}$ tersebut dikategorikan dalam gaya mengajar klasik. Berbeda dengan yang satu ini yaitu dosen dalam proses penyampaian memberikan stimulan pada mahasiswa untuk dijawab. Proses penyampaian yang seperti itu dikategorikan dalam gaya mengajar teknologis. Hal tersebut muncul dalam kelas C dan F. Selain itu, dalam proses penyampaian pelajaran di kelas D dan F muncul percakapan dua arah. Dengan demikian terjadi tanya jawab atau timbal balik antara dosen dengan mahasiswa. Kondisi seperti ini dikategorikan sebagai gaya mengajar interaksional. Dalam proses pembelajaran dosen pada kelas F memandang mahasiswa sebagai pribadi yang sedang belajar. 
Pada kelas D dan C terjadi percakapan dua arah antara mahasiswa dan dosen. mahasiswa dapat mengemukakan pendapatnya yang berhubungan tentang realita di kehidupannya dengan penuh percaya diri. Selain itu, mahasiswa juga mendengarkan pendapat temannya, sehingga ketika ada mahasiswa yang sedang menjawab pertanyaan dosen, mahasiswa lain menyimak. Keadaan yang demikian dikategorikan dalam gaya mengajar dosen personalisasi dan interaksional.

Seperti halnya dosen pada kelas F dan D, Dosen menggunakan metode pembelajaran yang sering digunakan yaitu metode ceramah ceramah, tanya jawab dan penugasan. Ketiga metode inilah yang paling sering menghiasi proses pembelajarn. Kondisi demikian termasuk gaya mengajar personalisasi. Menurut Chairy (2005) menjelaskan bahwa Kualitas pengajaran dan standar akademik perlu untuk selalu dievaluasi dan ditingkatkan karena pendidikan tinggi merupakan kegiatan yang mahal. Mahasiswa dapat menilai kinerja dosen melalui penguasaan kompetensi dosen. Oleh karena penilaian ini didasarkan atas persepsi selama berinteraksi antara dosen dengan mahasiswa maka penilaian ini disebut penilaian persepsional. Kualifikasi akademik dan unjuk kerja, tingkat penguasaan kompetensi sebagaimana yang dinilai orang lain dan diri sendiri, serta pernyataan kontribusi yang dinilai berdasar persepsi individu yang bersangkutan maupun bersama-sama, akan menentukan profesionalisme dosen.

Tabel 1 Teaching Style Dosen dalam Mengajar Matakuliah Evaluasi Pendidikan SD

\begin{tabular}{|c|c|c|c|c|c|}
\hline \multirow[t]{2}{*}{ Indikator } & \multirow[t]{2}{*}{ Item yang muncul } & \multicolumn{4}{|c|}{ Sub Variabel } \\
\hline & & Kelas F & Kelas D & Kelas C & Kelas E \\
\hline \multirow[t]{4}{*}{ Bahan Pelajaran } & $\begin{array}{l}\text { Sejumlah informasi dan ide yang } \\
\text { sudah populer }\end{array}$ & Klasik & Klasik & Klasik & Klasik \\
\hline & Diketahui mahasiswa & Klasik & Klasik & Klasik & Teknologis \\
\hline & Bersifat jelas dan logis & Personalisasi & klasik & Teknologis & Personalisasi \\
\hline & Bersifat obyektif, jelas dan logis & Klasik & - & Klasik & klasik \\
\hline \multirow{5}{*}{$\begin{array}{c}\text { Proses } \\
\text { Penyampaian }\end{array}$} & Hanya didasarkan urutan tertentu & Klasik & klasik & Interaksional & Interaksional \\
\hline & $\begin{array}{l}\text { Proses penyampaian komunikatif } \\
\text { dan santun dalam berbahasa. }\end{array}$ & - & klasik & Klasik & Klasik \\
\hline & $\begin{array}{l}\text { Memberi stimulan siswa untuk } \\
\text { dijawab }\end{array}$ & Teknologis & teknologis & Teknologis & Teknologis \\
\hline & Dua arah & Interaksional & Interaksinal & Interaksional & Interaksonal \\
\hline & Tanya jawab dosen dengan siswa & Interaksional & Interaksional & Interaksional & Interaksonal \\
\hline \multirow[t]{5}{*}{$\begin{array}{c}\text { Peran } \\
\text { mahasiswa }\end{array}$} & $\begin{array}{l}\text { Mempelajari apa yang bermanfaat } \\
\text { pada dirinya }\end{array}$ & - & Teknologis & - & Teknologis \\
\hline & $\begin{array}{l}\text { Merespon apa yang diajukan } \\
\text { kepadanya dengan bantuan media }\end{array}$ & - & Teknologis & Personalisasi & Personalisasi \\
\hline & Dipandang sebagai pribadi & Personalisasi & - & Personalisasi & Interaksional \\
\hline & $\begin{array}{l}\text { Mengemukakan pendapatnya } \\
\text { tentang realita }\end{array}$ & Interaksional & Interaksional & Interaksional & klasik \\
\hline & $\begin{array}{l}\text { Mendengarkan pendapat } \\
\text { temannya }\end{array}$ & Interaksional & Interaksional & Interaksional & Interaksional \\
\hline \multirow[t]{2}{*}{ Peran dosen } & Dominan & Klasik & Klasik & Klasik & klasik \\
\hline & Hanya menyampaikan bahan ajar & Klasik & Klasik & klasik & klasik \\
\hline
\end{tabular}




\begin{tabular}{|c|c|c|c|c|c|}
\hline \multirow[t]{2}{*}{ Indikator } & \multirow[t]{2}{*}{ Item yang muncul } & \multicolumn{4}{|c|}{ Sub Variabel } \\
\hline & & Kelas F & Kelas D & Kelas C & Kelas E \\
\hline & Otoriter & Klasik & Klasik & klasik & klasik \\
\hline & Ahli & Klasik & Klasik & klasik & Teknologis \\
\hline & $\begin{array}{l}\text { Membimbing mahasiswa dalam } \\
\text { belajar }\end{array}$ & Teknologis & Teknologis & Teknologis & Interaksional \\
\hline & $\begin{array}{l}\text { Memberikan petunjuk pada } \\
\text { mahasiswa dalam belajar }\end{array}$ & Teknologis & - & Interaksional & Interaksional \\
\hline & $\begin{array}{l}\text { Memberikan kemudahan siswa } \\
\text { dalam belajar }\end{array}$ & Teknologis & - & Teknologis & Teknologis \\
\hline & Menguasai metode pengajaran & Personalisasi & Personalisasi & Personalisasi & Personalisasi \\
\hline
\end{tabular}

Tabel 2 Analisis Penilaian Dosen Saat Mengajar di dalam Kelas

\begin{tabular}{|c|c|c|c|c|c|}
\hline \multirow[t]{2}{*}{ ASPEK } & \multirow[t]{2}{*}{ INDIKATOR } & \multicolumn{4}{|c|}{ PENILAIAN } \\
\hline & & $\mathbf{F}$ & D & $\mathbf{E}$ & $\mathbf{C}$ \\
\hline \multirow[t]{4}{*}{ PERSONAL } & 1.1 Kerapian dan Kesopanan dalam berpenampilan & $\sqrt{ }$ & $\sqrt{ }$ & $\sqrt{ }$ & $\sqrt{ }$ \\
\hline & $\begin{array}{l}\text { 1.2 Dosen memulai kuliah tepat waktu sesuai } \\
\text { jadwal }\end{array}$ & - & $\sqrt{ }$ & - & $\sqrt{ }$ \\
\hline & $\begin{array}{l}\text { 1.3 Dosen mengakhiri kuliah tepat waktu sesuai } \\
\text { jadwal }\end{array}$ & $\sqrt{ }$ & $\sqrt{ }$ & $\sqrt{1}$ & $\sqrt{ }$ \\
\hline & 1.4 Dosen tidak pernah absen & $\sqrt{ }$ & $\sqrt{ }$ & - & $\sqrt{ }$ \\
\hline \multirow[t]{5}{*}{$\begin{array}{c}\text { TEKNIK } \\
\text { MENGAJAR }\end{array}$} & $\begin{array}{l}\text { 2.1Volume berbicara saat mengajar Metode Model } \\
\text { Media }\end{array}$ & $\sqrt{ }$ & $\sqrt{ }$ & $\sqrt{ }$ & $\sqrt{ }$ \\
\hline & 2.2 Tempo Bicara & - & $\sqrt{ }$ & - & $\sqrt{ }$ \\
\hline & 2.3 Pilihan kata dalam menyampaikan materi & $\sqrt{ }$ & $\sqrt{ }$ & $\sqrt{ }$ & $\sqrt{ }$ \\
\hline & 2.4 Semangat dalam mengajar & $\sqrt{ }$ & $\sqrt{ }$ & $\sqrt{ }$ & $\sqrt{ }$ \\
\hline & $\begin{array}{l}2.5 \text { Penggunaan geraka, ekspresi mata untuk } \\
\text { menarik minat }\end{array}$ & - & $\sqrt{ }$ & $\sqrt{ }$ & $\sqrt{ }$ \\
\hline \multirow[t]{3}{*}{ AKADEMIK } & $\begin{array}{l}\text { 3.1 Manfaat mata kuliah bagi mahasiswa dalam } \\
\text { dunia kerja }\end{array}$ & $\sqrt{ }$ & $\sqrt{ }$ & $\sqrt{ }$ & - \\
\hline & $\begin{array}{l}\text { 3.2 Kemudahan mahasiswa dalam memahami } \\
\text { materi kuliah }\end{array}$ & $\sqrt{ }$ & $\sqrt{ }$ & $\sqrt{ }$ & $\sqrt{ }$ \\
\hline & $\begin{array}{l}\text { 3.3 Memberi contoh nyata terhadap setiap materi } \\
\text { kuliah }\end{array}$ & $\sqrt{ }$ & $\sqrt{ }$ & $\sqrt{ }$ & $\sqrt{ }$ \\
\hline KESELURUHAN & $\begin{array}{l}\text { 4.1 Secara keseluruhan apakah anda puas dengan } \\
\text { matakuliah ini }\end{array}$ & $\sqrt{ }$ & $\sqrt{ }$ & $\sqrt{ }$ & $\sqrt{ }$ \\
\hline
\end{tabular}

Pada dasarnya setiap manusia mempunya ciri khas sendiri yang tidak bisa ditirukan oleh orang lain seperti halnya gaya. Meskipun pada bidang yang sama belum tentu gayanya sama. Sedikit banyak pasti menunjukkan kekhasan dari seseorang dalam menunjukkan pada orang lain. Begitu pula dengan gaya mengajar. Setiap guru pastinya memiliki gaya mengajar sendiri yang khas dan tidak dapat ditiru oleh orang lain. Menurut Ali, dkk (2010), gaya mengajar yang dapat dibedakan menjadi empat macam yaitu gaya teknologis gaya mengajar klasik, dan,serta personalisasi dan interaksional. Masing-masing gaya mengajar mempunyai karakteristik sendiri yang berbeda dan sangat mudah untuk dibedakan. Berdasarkan hasil analisis data observasi pada pembahasan 
sebelumnya, dapat diketahui bahwa bahan matakuliah evalausi yang disiapkan oleh dosen kelas F, D dan E Dan C termasuk dalam kategori gaya mengajar klasik. Hal ini diperkuat dengan hasil wawancara kepada dosen yang bersangkutan yang mengatakan bahwa informasi popular mempercepat pemahaman siswa. Bangku mahasiswa dan meja dosen di ruang kelas $\mathrm{C}$ dan $\mathrm{F}$ sudah diatur membentuk huruf U. Bangku mahasisiwa ada di sebelah utara, timur dan selatan. Bangku dosen berada di sebelah selatan dekat pintu masuk kelas. Artinnya adalah manajemen pengelolaan kelas sudah direncanakan dengan matang sehingga Kondisi seperti ini membuat ruang kelas bagian tengah menjadi luas. Hal ini memudahkan dosen untuk menjangkau setiap mahasiswa. Kondisi seperti ini dibenarkan oleh Djamarah, Syaiful Bahri dan Zain (2010) yang mengatakan bahwa formasi tempat duduk dapat digunakan sesuai dengan kebutuhan. Kondisi kelas berbeda dengan di kelas $\mathrm{F}$ dosen kelas $\mathrm{C}$ masih menerapkan sistem pembelajaran klasikal dengan gaya khas tidak mengubah posisi meja mahasiswa dan meja dosen . Posisi berderet dengan jumlah siswa kurang lebih 10 siswa setiap deretnya.

Pada kelas D dan E kegiatan pembelajaran dimulai dengan salam kemudian apersepsi. Setelah itu dosen menyampaikan tujuan pembelajaran dan menjelaskan kegiatan-kegiatan yang akan dilaksanakan selama proses pembelajaran. Hal ini bertujuan agar mahasiswa lebih bersemangat mengikuti pembelajaran. Kondisi seperti ini sejalan dengan Rusman,Djaelani (2012)yang mengemukakan bahwa bila mahasiswa mengetahui tujuan pembelajaran yang sedang mereka ikuti, maka mereka akan terdorong untuk melakukan kegiatan tersebut secara aktif. Proses penyampaian materi oleh dosen dikategorikan dalam gaya mengajar klasik, teknologis dan interaksional. Namun ada satu item yang muncul di luar dugaan peneliti bahwa salah satu dosen masih mendidik mahasiswa dengan budaya yang dianggap benar. Seperti halnya menurunkan nilai-nilai terdahulu pada generasi berikutnya dengan memberikan nasehat dan pesan moral untuk terus belajar. Hal ini sejalan dengan Ali, dkk, (2010) yang menyatakan bahwa setiap generasi harus bisa dididik dengan budaya yang dianggap benar dan sahih. Isi materi lebih banyak mengenai dasar pembentukan intelek serta pendalaman karakter dan komunikasi dengan dunia luar. Proses penyampaian tersebut sudah jelas tergolong dalam gaya mengajar klasik. Hasil wawancara menunjukkan bahwa dosen pengajar kelas $\mathrm{C}$ jarang menggunakan media pembelajaran. Hal ini dikarenakan tanpa menggunakan media, pelajaran sudah diterima dengan baik oleh Mahasiswa. Dosen hanya menggunakan media ketika pelajaran benar-benar membutuhkan media untuk lebih memperjelas pelajaran yang disampaikan dosen. Berbeda dengan guru kelas D yang berusaha untuk menggunakan media setiap pembelajaran apabila medianya mudah untuk dicari. Antara keduanya mengemukakan alasan bahwa penggunaan media pembelajaran disesuaikan dengan isi pelajarannya. Apabila sudah cukup hanya dengan penjelasan Dosen, maka media tidak perlu ada. Namun keduanya sepakat bahwa membuat dan menggunakan media itu ribet. Hal tersebut sejalan dengan pendapat Thomas Wibowo (dalam Sundayana S. dkk, 2014) bahwa sekurangkurangnya terdapat 7 alasan guru mengajar enggan menggunakan media pembelajaran, yaitu (1) menggunakan media itu repot, (2) media itu canggih dan mahal, (3) tidak bisa mengoperasikan media pembelajaran, (4) media itu hiburan (membuat siswa main-main, tidak serius), sedangkan belajar itu serius, (5) tidak tersedia media pembelajaran di lembaga perguruan tinggi, (6) kebiasaan 
menikmati ceramah/bicara, (7) kurangnya penghargaan dari atasan. Sehingga kalaupun ada media yang ingin digunakan dosen yaitu berupa media perangkat keras yang bisa langsung dilihat dan dipegang oleh mahasiswa. Hasil observasi peran mahasiswa dalam proses pembelajaran tergolong personalisasi, interaksional dan teknologis. Sedangkan peran guru dikategorikan dalam gaya mengajar dan klasik, personalisasi.

Berdasarkan uraian di atas, penelitian tentang gaya mengajar dosen kelas C,D,E,F yang ada di Universitas kanjuruhan Malang sesuai dengan teori yang dikemukakan Ali, dkk (2010)dengan perbedaan masing-masing gaya mengajar dapat terlihat ketika peneliti melakukan pengamatan langsung selama beberapa kali pertemuan pembelajaran. Seorang dosen yang kreatif pasti akan menggunakan gaya mengajar yang tepat sesuai dengan kondisi kelas dan isi pelajaran. Jika perlu guru harus bisa membuat variasi gaya mengajar agar tidak membuat mahasiswa merasa bosan. Karena berawal dari bosan, akan berdampak pada kemauan belajar siswa dan pada akhirnya prestasi belajarnya menurun. Dosen yang sudah mantap dengan satu gaya mengajar sebaiknya lebih mengembangkan dan membuat variasi atau mengubah gaya mengajarnya. Hal ini sejalan dengan Ali, dkk, (2010) menyatakan Dosen yang sudah mantap mengajar dengan menggunakan gaya mengajar tertentu, dapat pula mengubah gaya mengajarnya. Untuk itu sebelum suatu gaya mengajar ditampilkan di hadapan mahasiswa, terlebih dahulu perlu dilatih atau mengadakan latihan bersama dengan kolega. Untuk itu, seorang dosen harus meiliki pemahaman terlebih dahulu. Begitu pentingnya sebagai seorang dosen harus memiliki pemahaman tentang gaya mengajar dosen yang berbeda beda., setidaknya harus memahami macam macam gaya mengajar dosen, sehingga dosen bisa lebih kreatif dalam mengembangkan pengetahuan dan wawasannya. Seperti diketahui sesuai denggan UU no 12 tahun 2012 bahwa tugas Dosen adalah menjalankan Tri Dharma Perguruan tinggi yaitu Pedidikan, Penelitian dan Pengabdian pada Masyarakat. Namun pada pembahasan penelitian ini hanya difokuskan pada pengajaran dosen pada bidang Pendidikan. Kegiatan Belajar Mengajar merupakan interaksi yang melibatkan Dosen dan mahasiswa. Sehingga disinilah para mahasiswa berperan penting dalam penilaian gaya mengajar dosen. Mahasiswa sebagai user memiliki persepsi yang lebih obyektif dalam menilai kinerja dosen dalam pelaksanaan LKBM khususnya di lingkungan Akademi Universitas kanjauruhan Malang. Berikut ini adalah table kinerja Dosen pengejaran style mengajar Pada matakuliah Evaluasi Pendidikan

\section{KESIMPULAN DAN SARAN}

Berdasarkan hasil penelitian yang diuraikan pada bab sebelumnya, dapat diambil kesimpulan bahwa Dosen di universitas kanjuruhan Malang menggunakan gaya mengajar klasik, namun diselingi dengan gaya mengajar lainnya yaitu teknologis, personalisasi dna interaksional. Dosen berupaya membuat variasi gaya mengajar dalam pembelajaran, namun belum terlihat jelas sepenuhnya karena setiap pengajar memiliki kompetensi dan style masing masing.

Segala yang telah dilaksanakan pasti tidak lepas dari ketidaksempurnaan. Setelah mengadakan penelitian dan terlibat langsung di dalamnya, peneliti akan menyumbangkan sedikit saran sebagai berikut. (1) kaprodi sebaiknya memberikan evaluasi dan saran yang tepat bagi Dosen guru kelas maupun dosen lainnya untuk 
menggunakan variasi gaya mengajar yang sesuai dengan kondisi pembelajaran. (2) dosen Guru kelas sebaiknya menggunakan gaya mengajar yang bervariasi agar lebih menambah kualitas mengajarnya, menggunakan gaya mengajar yang membuat mahasiswa lebih bisa memahami materi, menggunakan berbagai metode mengajar yang kreatif dan aktif sehingga mampu membentuk sikap inspiratif mahasiswa. (3) bagi peneliti lain untuk melanjutkan penelitian tentang gaya mengajar dosen pada jenjang perkuliahan sehingga semakin memperluas ilmu pengetahuan tentang realita pelaksanaan pendidikan di universitas bahwa setiap dosen memiliki kelebihan kompetensi mengajar dengan style yang berbeda-beda karakter

\section{DAFTAR RUJUKAN}

Ali, Dkk, M. (2010). Guru dalam Proses Belajar Mengajar. Bandung: Sinar Baru Algensindo.

Djamarah, Syaiful Bahri dan Zain, A. (2010). Belajar Mengajar. Jakarta: Rineka Cipta.

Embong, A. M., Noor, A. M., Hashim, H. M., Ali, R. M., \& Shaari, Z. H. (2012). E-Books as Textbooks in the Classroom. Procedia - Social and Behavioral Sciences, 47, 1802-1809. https://doi.org/10.1016/j.sbspro.2012.06.903

Moleong, L. (2006). Metodologi Penelitian Kualitatif. Bandung: Remaja Rosdakarya.

Rusman,Djaelani, dkk. (2012). Model-Model Pembelajaran dalam Mengembangkan Kompetensi Profesionalisme Guru. Jakarta: Rineka Cipta.

Satori, D dan Komariah, A. (2011). Metodologi Penelitian Kualitatif. Bandung: Alfabeta.

Satori, D. dkk. (n.d.). Profesi Keguruan. Banten: Universitas Terbuka.

Sugiyono. (2011). Metode dalam Penelitian Kuantitatif Kualitatif dan R\&D. Bandung: Alfabeta.

Sundayana S. dkk. (2014). Media dalam Pembelajaran Matematika. Bandung: Alfabeta.

Thoifuri. (2013). Menjadi Guru Inisiator. Semarang: RoSAIL Media Group. 